FACTA UNIVERSITATIS

Series: Linguistics and Literature Vol. 18, N ${ }^{\circ}$ 1, 2020, pp. 119-129

https://doi.org/10.22190/FULL2001119A

Original Scientific Paper

\title{
THE DOUBLINGS IN A SHORT STORY COLLECTION STARI DANI BY BORISAV STANKOVIĆ
}

UDC 821.163.41.09-32 Stanković B.

\section{Milica Aleksić}

Pedagogical Faculty in Vranje, University of Niš, Serbia

\begin{abstract}
In this paper we discuss the doubling of characters' identities in Borisav Stanković's short story collection Stari dani (1902), and a conscious or unconscious selection of another protagonist as an alternative for performing a particular protagonist's activity the doubling of the actual narrative world through counternarrative, simulated narrative, comparison and narrative negation will be analyzed. We will try to show how the patriarchal context determines this otherness of worlds and protagonists, and what the cause-effect relations has to do with the psychologization of Stankovic's protagonists and the development of the story in nine short stories of the aforementioned collection.
\end{abstract}

Key words: Borisav Stanković, identity doubling, replacement of the protagonists, virtual narrative, Stari dani

\section{INTRODUCTION}

The short story collection by Borisav Stanković Stari dani (1902) is entirely in dualities and otherness, which are reflected in the protagonists and the narrative plan. In the patriarchal environment, described by Bora Stanković, an individual is always in a silent conflict with the collective, therefore his inner world is in opposition to the outer one, in which he exists. In order to make a protagonist's behavior socially acceptable, it becomes a type of simulation, an alternative to what that protagonist feels or what he wants to do. Such an atmosphere, in which "story [...] is developing from the inside to the outside, from the close to the open space" (Deretić 2007, 1001), results in doubling of narrative worlds, as well as in doubling of identities of the characters. In terms of the literary character, doubling takes place by giving one protagonist another identity in the eyes of the environment or by replacing one protagonist with another. With this artistic process, a literary protagonist gets

Submitted May 14, 2020; Accepted May 21, 2020

Corresponding author: Milica Aleksić

Pedagogical Faculty in Vranje

E-mail: milica.aleksic.06@gmail.com 
his doppelganger in himself or in another person, while doubling on the narrative terms implies an existence of virtual narratives as parallel, alternative worlds. With these narrative processes, the short story collection Stari dani, and other works of prose by Borisav Stanković lead to the layering or disintegration of realism (cf. Ivanić 1996, 70-73). Thereby, short stories Đurđev-dan (Saint George's Day) and U vinogradima (In the Vineyards) are closer to realistic short story, while the other seven: U noći (In the Night), Stanoja (Stanoja), Nuška (Nuška), Naš Božić (Our Christmas), Stari dani (The Old Days), Oni (They) and Pokojnikova žena (The Deceased's Wife) largely announce Serbian modernism through their narrative technique and thematic-motive layer.

\section{THE DOUBLING OF CHARACTERS}

While the poetics of realism is characterized by a mimetic portrayal of characters, their doubling in Stanković's narrative texts brings destruction to that mimetic conception, which is motivated by the psychological states of the protagonists or the patriarchal context in which they exist. Accordingly, one protagonist may have two identities, or he may replace his position with the position of another protagonist, so we are talking about doubling the identity of the protagonist or about the protagonist as the alternative to another protagonist.

\subsection{Doubling of protagonist's identity}

The protagonist of the short story Pokojnikova žena Mita exists in two mental spaces, and therefore he has two identities: in the past - as alive, and in the present - as the deceased. Between two possibilities, Anica chooses the second one, which is motivated by the patriarchal code of conduct of a widow: Toliko mu je već izlazila, a i sada izlazi na grob, da ga je kao živoga gotovo zaboravila i pamti ga samo po grobu (Stanković 1980, 228). The space in which, in the present moment, this protagonist exists is the only memory of widow Anica and her environment, as the mental space in which the deceased takes an inviolable position, and which cannot be violated in any way. The environment treats Anica carefully, fearing that inappropriate visits or conversations would violate respect for the deceased and his peace, as his presence was still felt in the silence of the empty and physically altered house. If they visited Anica they would only talk about the deceased, and this always reminded Anica that Mita was not truly dead, but alive, by talking about him and equating the private space of their family house with his own space: Bilo u bašti, kući, svuda, svuda je bio on; sve je bilo njegovo (Stanković 1980, 254).

There is the doubling of Anica's identity as well. The first one is the one she truly poses, i.e. Anica, and the other one is the one which is generally accepted, the identity she has in the eyes of those around her - the wife of deceased. A girl in a patriarchal society develops her identity only by marriage as the initiation. Anica felt gratitude towards the late Mita for he let her into his house bringing order into it. Therefore, she was his, and nobody could think about her badly if only she looked at him, which would not have been the case when she was a girl. Marriage changes the status of a woman in society, changing her identity. Gratitude for that makes Anica consider herself his even after her husband's death. This is also the reason why she rejects Ita's marriage proposal, her first love. Anica does not see in herself a woman worthy of such ideal love because she is no longer herself, but someone else's - and not Ita's, but the deceased's. I kako će ona da ga primi, zagrli, kao njegova? 
Možda bi uvek osećao kako mu nije došla čista, kad je grli, ljubi, već je drugoga, pokojnikova... jednom već grljena, milovana (Stanković 1980, 260-261). Her purity belongs to the past, to the girlhood, to the original identity of Anica, which she renounced when she married Mita, by choosing, as an alternative, the identity of being his wife. Even when she was a girl she could not simply be Anica in the social setting, but again her identity was determined by the male members of the family: A ona, Anica, jedino se po toj svojoj braći $i$ znala. Niko nju nije zvao njenim imenom već "sestra na Ribinčiki" (Stanković 1980, 236). This alternative is again chosen by the society, not by herself. That indicates an utterly devastating and inferior position of a woman in a patriarchal society, she can never be what she really is, but always gets her identity by others.

The only time Anica choose her identity in relation to someone else is when during her wedding celebration she is left alone with Ita; concealing the pain from the inability to accomplish their love, she makes an effort to da se pokaže samo kao sestra, snajka, a ne drugo (Stanković 1980, 245). Although this alternative is for the first time her choice, again it is indirectly the choice of the patriarchal community: the brothers chose Anica to marry another person, and Ita to be only a brother-in-law instead of the groom. Thereby, Anica becomes his sister and sister-in-law instead of Ita's wife. When she later gets the opportunity to accomplish her original desire, she refuses because she already has had the identity of the deceased's wife, which is a direct obstacle to achieving the goal.

In the short story Naš Božić, the topos of the holiday was motivated by the doubling of the identity of the character-storyteller. Having lost his father early, this boy lives with his mother in bad material conditions. Nevertheless, the happiest Christian holiday will make the boy become someone else, at least on that day. On that day, his mother and the guests will address him as the host, so they will treat him with greater respect, as the older, that is, the male head of the family. His mother will even lose herself in that joy, and she almost kisses his hand, instead of him kissing her hand. The new shoes and formal clothes, which the boy eagerly tries on before Christmas are the symbol of the child's desire to grow up as soon as possible and become someone else, an adult and a host. Christmas is different from any other day, and so is the status of the boy in the family: Sada me i majka već ne grdi, ako štogod slomim, a kamo li da me bije, jer "lošo" je pred Božić. Čak me drukše nekako i gleda. Ne kao majka, već nekako drukčije, ponizno, kao starijeg od sebe (Stanković 1980, 172). That otherness, diversity, motivated by a person's religious feeling, brings a new identity to the boy. The chronotope of Christmas determines the boy's new identity, because the character himself is "always essentially chronotopic" (Bahtin 1989, 194), defined by the time and space in which he exists.

In the short story Oni, doubling of the identity of the patient Mita is psychologically motivated. From an excessive desire to be healthy as before, Mita's parents see in Mita's best friend Ariton his doppelganger:

Čudo, kako su se Aritonu svi pokoravali, slušali ga. Ali moglo se videti, da to oni čine zbog toga, što misle da što god im on kaže, zapovedi im, da to njihov Mita hoće, da kroz njega on govori. Ariton je to znao, pa je zato bio slobodan, osoran. Sve ih je kao grdio, što ga toliko čuvaju, strepe i time mu slute neko zlo. A to je baš njima i godilo, $i$ zato su ga slušali (Stanković 1980, 218).

Ariton is the same age as their son, so in his health and authoritative behavior, Mita's parents see a copy, a doubling of their son as they would love to be able to see him, instead of a weak person on his deathbed. On the other hand, Ariton is a young man 
without parents, so it is not difficult to recognize his psychological need for the position of the son of someone else's parents and the satisfaction he feels during that alternation.

\subsection{Protagonist as an alternative to another protagonist}

While the process of replacing one protagonist with another in comic discourse, qui pro quo and error in persona (cf. Lešić 1981, 194-203), leads to a humorous effect, in Stanković's prose it is a consequence of the protagonist's inability to freely accomplish a process related to one protagonist, so he directs his original intention towards someone else. An individual is always in a conflict with the patriarchal community and emerges from that conflict defeated; replacing the protagonist with his alternative takes on the outlines of tragedy, sometimes irony, or is simply a sign of his weakness and inability to express his emotions and desires.

Thus, Ita, in Pokojnikova žena, instead of giving food to Anica out of compassion and love, he allegedly sends it to her child as on orphan without father, in order not to call in question Anica's honor of a young widow with his attention. Due to the feeling of unworthiness of great and ideal love, as well as due to the guilt she feels towards memory of the deceased, Anica chose Nedeljko over Ita, though he was a worse choice for two reasons: she did not love him, and he was also a poor widower with three children. Neither psychological nor social barriers prevented her from choosing an alternative that no one could find the reason for. Ita proposed to her, and she consciously relinquished happiness by turning to another protagonist as his alternative. This replacement of protagonists led to tragedy in Anica's destiny of a woman defeated by the patriarchal society in which she lived.

Renouncing her luck with Ita, in some sort of insanity Anica cries and mourns Ita as if he were dead, not Mita. Now the deceased gets his alternative in Mita: Ito, Ito moj... - I kao da je mrtav, počne da kuka, oplakuje ga (Stanković 1980, 260). Ita is one possible alternative for the deceased, and the other one is Anica herself. She mourns the deceased out loud, but not so much because she really grieves him, but punishing herself for not feeling much sad, contrary to expected. Ono njeno "lele, Mito!" ko zna zašto je bilo. Da li je taj plač bio za njega ili za nju, samu sebe (Stanković 1980, 250). Therefore, Anica by mourning the deceased, actually mourns herself, so that in this action of hers we recognize the substitution of one protagonist for another.

Her child, going with mother to father's grave, take on her pattern of behavior, imitates her in terrible sobbing and crying, which Anica interrupts with an order to her little son not to cry, as the two of them are not the same: Ne gledaj ti nanu, čedo... Zar zato što vidiš da nana plače, pa i ti da plačes. Ne gledaj ti nanu. Drugo je nana...Nemoj. Lošo će mi ti je (Stanković 1980, 230). In the statement "drugo je nana" Anica's readiness to accept her own grief instead of the child is recognized: she is the one who is expected to grieve and cry, and not the child. She wants to protect the child by choosing herself as the victim. Patriarchally raised, the protagonist chooses and puts herself out as the carrier of the tribulation and suffering, and in the case of Mita, as the cause of grieve as well - she grieves herself.

The protagonist of the short story Stanoja is secretly in love with Kata, to whose husband he is a servant. When he hears the husband is beating her, Stanoja without thinking breaks into the house to defend her, and on that occasion the perpetrator hurts his head instead of the woman's. Stanoja's acceptance of the position of an alternative protagonist is also motivated by love, even when he takes care of her children instead of sick Kata. He brings her fruits with the greatest care, even though he is a poor man, so when she accepts 
this gift, Stanoja hugs and kisses her children out of a joy. Now the collective character of the children becomes an alternative for Kata: all the love that Stanoja cannot show towards her, in the collective image of the children he gets an alternative recipient.

When she cannot accomplish her love with gazda ${ }^{1}$ Stojan, with whom she fell in love when she was a child, Cveta in the short story $U$ noći autoerotically conveys passion to herself as an object of desire: I ne mogući da izdrži više, besno, mahnito ljubljaše i ugrizaše prsa, gojne mišice na ruci, gurajući pesnicu u usta, kao da bi sprečila ono što iz nje izbijaše i svu je obuzimaše (Stanković 1980, 142). Autoerotization connects Cveta with the protagonist of Nečista krv, Sofka, who also transmits passion to herself in the absence of the ideal man, but this alterity of protagonists can be subsumed under doubling of identity, and not under the replacement of protagonists: Sofka recognizes in herself some other self, the duality of her being, because she only daydreams about hypothetical, ideal man, while Cveta loves one particular man. Cveta's self-destructive directing of passion towards herself is close to the self-destruction or destruction of Ćorović's protagonists of oriental tales who, due to karasevdah ${ }^{2}$, inflict harm on themselves (Latinkal A Catholic), the object of desire (Sa nenom/ With aunt) or her rival (Osman-begova šargija/ Osman-beg's shargia), because in all mentioned texts "Eros, as unused positive energy, is turned into a complete destructive mare" (Maksimović 2014, 236).

Alternatively, the protagonist of the short story $U$ noći in her youthwas married to Jovan without her knowledge, and then Stojan was married to another girl. That alterity of the protagonists is motivated by social difference - Stojan was the master, and Cveta was a servant in his house. The rift between desire and reality made Stojan unhappy, thereby he didnot look at the unwanted woman at all. His father first threatens to kill him in anger, and a moment later he changes the roles of the killer and the victim, in desperation he subverts himself as an alternative protagonist ${ }^{3}$, whom now Stojan has to kill. With this replacement of the protagonists' positions Stojan will see all the weight of his father's position and shame, for which he is to blame. For that reason, he will change his behavior towards his wife and stop wandering. Therefore, the procedure of replacing the protagonist with another in this case gained importance in the further course of events, while in Cveta's case it has a static function and is important only for the sake of her psychologization.

The motif of a forced marriage with an unloved is a common place in Stanković's prose. Instead with the beloved girl, Mita, the protagonist of the short story Oni, is forced to marry another girl by his parents. At the time of the story, Mita is dying of some mysterious illness, so Petković $(2009,165)$ points out the confirmation of the mystery of Mita's illness, not only through silence, but also through the behavior of his parents and wife: "as if they were all hiding something, and as if some vague guilt was floating in the air". Marriage to an alternative protagonist opens the possibility of further doubling of the worlds, because in addition to one possible cause, some organic disease, there is another possibility - a silent death of protagonists for love, as a common place in Stanković's prose, where protagonists are dying physically or spiritually due to karasevdah and the prohibition of love by the patriarchal society.

\footnotetext{
${ }^{1}$ Serbian gazda is a title next to the name of a wealthy man; master, patron, host, sahib.

${ }^{2}$ Karasevdah is a Turkish word for great love desire, mental suffering, sadness, depression over unfulfilled love.

${ }^{3}$ This scene has its counterpart in the scene from the novel Nečista krv, in which efendi Mita kneels before Sofka, thus pointing out to her the ultimate humiliation of his, and inevitability of her marriage to Tomča. Once again, the father, as the head of the family, kneels before his child, humiliated, and begs for help.
} 
The inability to express strong love feelings in $N u s ̌ k a$ leads to the double replacement of the beloved being with a character-storyteller, who is still a child at the time of the story. In love with the proud Nuška, Mladen does not let any girl dance beside him in $k l_{0}{ }^{4}$, except for a small character-storyteller, in which he finds an alternative for Nuška. He tries to get close to Nuška through the affection for this child, by replacing him with her: I da joj, valjda, pokaže kako je voli, on kad kolo povede, ne pušta nijednu devojku do sebe, već uzme mene, njenog rođaka... kao da sam ja nešto ona! A Nuška se na to samo osmehne, prevuče očima $i$-ne gleda ga! ... (Stanković 1980, 165). Blushing and excited, Nuška hugs her little cousin instead of Mladen, which, due to the patriarchal restrictions, projects the ability of expressing passion towards the beloved young man on to the innocent embracing and kissing of a child (cf. Milosavljević Milić 2013, 52-53). When unable to attend the wedding and dance, Nuška indulges in dancing at home, making the chronotope of the home an alternative to wedding joy, and Nuška's sensual dance becomes a simulacrum, a kind of dual or alternative mini-world over the primary one, in which the wedding is really taking place.

\section{ALTERNATIVE WORLDS}

Appearance of doubling of narrative worlds in Stanković's short story collection Stari dani is motivated by the rich psychologization of the characters and the conflict of the individual with the patriarchal environment, and the limited knowledge of the protagonists when it comes to focalized narration. Milosavljević Milić (2016: 53) distinguishes several types of virtual narrations: peripheral possible story (and within the counter-narrative and hypothetical focalization), narrative negations, comparisons and simulated narratives. All of them are characterized by major or minor deviations from the current story and greater or smaller possibility of realization.

\subsection{Simulated narrative}

Due to different expectations of the social environment, Stanković's protagonists are forced to behave in a way that substantially deviates from what they feel inside. Therefore, they start to play different roles, to simulate, or to pretend. Then doubling of that inner world of the protagonist - his awareness of something or his desires - proves to be the outness that is significantly different from the inner world of the protagonist or even completely opposite to it.

Unhappy in marriage with Mita, Anica, the protagonist of Pokojnikova žena, alternatively devotes herself to obsessively cleaning the house to hide the drama that is playing out in her soul. Mita notices her pretense, da se ona zato silom unosi u posao, da bi se time zanela, kao otresla, odvojila od nečega drugog... (Stanković 1980, 249), but cannot read her mind. When Mita says shortly: $D e, d e . .$. , forcing her to stop in her zealous work, a kind of pseudo-dialog, something unspoken and silent takes place between them, in which the protagonist knows not as much as than the omniscient storyteller (Richardson, 2014), but he infallible suspect that Anica is hiding something by doing this. After Mita's death Anica is forced to sit at sofra

\footnotetext{
${ }^{4}$ In Southeastern Europe, the South Slavic people traditionally dance the circle dance, known as kolo, named after the circle formed by the dancers.

${ }^{5}$ Sofra is a Turkish word for table, dining table.
} 
with mother and son, even if she does not eat, because that is the custom, then to sit with Ita in front of the house and not inside, so that the neighbors would not suspect something bad, to look down when returning from the cemetery, even though she feels anxiety in her chest and narrowness of her clothes - in one word, always to muffle what she really wants to do and to simulate the behavior of the exemplary young widow in accordance with the moral expectations of the patriarchal environment. Vukićević $(2011,17)$ rightly notes: "The "program" of social behavior is not only imposed on the protagonists, it is built into them in the form of self-censorship. Even in extreme situations (death of a dear person for example) the protagonists are under "surveillance" of the environment. And for their behavior to be in line with that surveillance and expectations, they need to simulate certain actions".

And for the protagonists of the short story Unoci $i$, it is typical to simulate the behavior contrary to what they would really like to do. For this short story Vučković $(2014,249)$ says that it is typical Stanković's position of lovers: "they consciously refuse one another, and subconsciously their souls fly to each other". Due to the inability to accomplish love, unhappy protagonists choose to run away from each other, which is a general pattern of behavior of Stanković's protagonists. In the retrospective segment about the youth of Stojan and Cveta, the escape is motivated by patriarchal shame and strong feelings that drive the protagonists in love to occasionally spite each other. ${ }^{6}$ While working in the fields, they tease each other, so at the end they "supposedly angry" go their own way. Ona, u tesnom jelečetu, povezana šamijom, s nestašnim i prkosnim osmehom na rujnim joj ustima, gleda ga krišom, vidi: kako se on češe, vrpolji, gleda u nju i hoće nešto da joj kaže, a ona mu tada okreće leđa i čini se nevešta (Stanković 1980, 135-136). By diversity of social position the prohibition of their love is motivated, so now Cveta must again conceal love in her behavior because she is someone else's wife. She simulates austerity and hatred towards Stojan, while she herself barely manages to control her love and passion for him.

Unhappy love is the main motif of the short story Oni. As an obedient and flawless son, young Mita, cannot tell his parents about his love for the poor gardener's daughter Mara due to patriarchal shame: On je hteo da oni, otac mu i majka, sami pogode koju on voli, i tu da mu uzmu za ženu. I mati mu je, istina, za to dočula, saznala, ali se činila tome nevešta, i pokatkad izdaleka nagoveštavala mu, kako mu je već otac izabrao drugu, ovu istu Mariku [...] (Stanković 1980, 214). His mother pretense that she does not know about Mita's love for Mara is socially motivated. Since Mita's parents struggled to get rich when they got married, the possibility of their son now marrying a poor girl was out of the question. Throughout his childhood, Mita was longing for parental warmth, because they pretended, simulated austerity, fearing that the outbursts of tenderness would not spoil his rigorous upbringing. The entire behavior of the parents was a simulation of a way of living that they thought it should be practiced. Therefore, in the end, their son tragically dies, his life was missed, and Mita's neglect conditioned by his parents' simulated behavior is indicated by the title of the story Oni. Although, all the time he is talking about Mita as the protagonist, about his illness and death, his youth, he is actually in the shadow of his parents all the time.

\footnotetext{
${ }^{6}$ This kind of behavior in retrospective segment about the youth connects these protagonists with young protagonists in love in Stankovic's short stories Đurđev-dan and $U$ vinogradima.

${ }^{7}$ The position of the protagonist in relation to the patriarchal context is similar in Stanković's short story Stari dani, where the entire first part of the text is dedicated to showing the collective character of people, by turning
} 
In the short story Naš Božić, the simulated narratives are motivated by a silent melancholy due to death of the father of the character-storyteller, so in certain situations his mother pretends that her child is older than he is, the host and head of the family, which is why he wears his father's much bigger clothes. And their relatives treat them carefully because of the social circumstances: Što je dolazilo, to došlo izjutra, na rakiju, kao da nas štede, jer znaju da nemamo, i zato su dolazili ujutru na rakiju, pošto se tada ne zaseda i ne pije tako mnogo (Stanković 1980, 182). There is a noticeable pretense in the behavior of both mother and the relatives: the mother acts as if her son has already grown up, and the relatives seem to be fine with this material situation despite the death of the head of the family, knowing that the truth is different, they strive not to endanger further their material condition. The arrival of Jovan, the father's brother and friend, greatly rejoiced the boy and his mother. The unspoken, inner mother's joy through tears that someone came to them on the holiday, the character-storyteller sees as the simulated narrative: [...] pa kao da mi veli: - Božić, sine. Vidiš li? (Stanković 1980, 185). In order not to encourage both the child's and her grief, even by a word of consolation in the statement mentioned, the mother keeps many things silent through the text, which the character - storyteller still recognizes based on her body language and gestures.

\subsection{Counter-narrative}

The protagonists of Stanković's prose, due to a limited knowledge in focalized narration, an emotional and psychological need for a better life or being defeated by the collective, run to a virtual world, which seems "superior in every aspect: psychological, ideological, aesthetic” (Milosavljević Milić 2016, 73). These are usually plans for the future, which are all the more distant from the current world of the story because they are uncertain and as such will never actually be accomplished. Such is an example of a counter-narrative in the short story Oni, where through internal focalization the plans of Mita's parents are presented when they live better and more comfortably: A to njihovo "ima kad" trebalo je da bude: kad još nekoliko njiva i vinograda kupe, kad im on, sin, Mita, poraste, pa ožene ga, $i$ on decu izrodi, te se kuća razgrana, učvrsti... tada (Stanković 1980, 211). The counter-narrative here includes a whole catalog of events that should take place in the future, so that Mita's parents can finally feel relief yet, through further prospection it is realized that this will not happen.

By protagonist's amorousness in the short story $U$ vinogradima the motivated counternarrative is also bound to the future time, which will remain unaccomplished:

Jer je znala, sigurna je bila da ćemo se ovde, u vinogradu, pomiriti. Da ćemo, kao $i$ lanjske godine, s jednog čokota zajedno brati grožđe, da ću da mećem u njenu kotaricu, služim se njenim kosirčetom, pa posle, kad počnemo zrna da skupljamo, da ću navlaš gurati moju ruku u njenu, a tada će prsti da nam se prepleću i glave, lica, kose dodiruju. I, naposletku, da ćemo iz mojih usta da "zobamo" zrno, ali tako da jedna polovina zrna ostane u mojim, a druga u njenim ustima... (Stanković 1980, 158)

the storyteller from stumbled people of the new to honest people of the old time. It is only in the second part that an individual in that collective will get his place, an individual from the social margin. Tomča, as a loner who drinks and wanders at night, with such a way of life, but also with the physical appearance of a torn and carelessly dressed man, deviates from the environment in which he lives. Everyone looks at him with some hidden pride and contempt, except for Pasa, whose life he once saved, and is now secretly in love with her. Such characterization of the protagonist is directly motivated by Tomča's missed life and unrealized love, which connects Tomča with Stanoja from Stanković's short story by the same name. 
Considering the events from the previous year, even though this counter-narrative has the potential for realization in the present time of the story, it will not happen due to the defiant character of the character-storyteller. This feature of his will be pointed out by the supporting character of the Gypsy woman, who at the end of the story tells fortune from the palm of his hand, revealing his difficult character, but the protagonist interrupts her, not wanting to listen further more. The counter-narrative mentioned signifies paralepsy (cf. Genet 1995, 83) because the character-storyteller is an intra-diegetic storyteller, and yet he penetrates the consciousness of another literary character, by expressing the expectations of this girl in love in the future.

A better, alternative world into which Cveta, the protagonist of the short story U noći, runs through her imagination, is a counter-narrative about running away with Stojan somewhere far away: A njoj tada dođe - sačuvaj Bože, kao neka napast! - da i ona, kao što se u pričama kazuje, poleti, sedne do njega na konja, obgrli ga, i da oboje, zagrljeni, na mesečini, preko polja i gora pobegnu daleko, daleko! ... (Stanković 1980, 140) The comment of the protagonist: "sačuvaj Bože, kao neka napast!" is of a moralizing character and belongs to the border sphere between the current and the virtual world. Formally, it belongs to the counter-narrative, but semantically it is a part of the current patriarchal world, in which the protagonist exists. In such a current world, it is not allowed to be ashamed and sinful or to think about another man, let alone run away with him, while in the virtual world, the protagonist is happy precisely thanks to the realization of this intention. That is why the mentioned comment of the protagonist is aimed at Cveta's attempt to distract herself from such thoughts, which she knows are sinful, which is supported by her prayers a moment later, and a warning of punishment for such a sin in the other world.

The protagonist of Pokojnikova žena Anica is close to Cveta in her escape to alternative world, in which she would accomplish her love with Ita: Nije da ga ne voli! Ah, samo jednom da ga oseti, pa da... Ali kako će? Kako će ona njega, Itu, da pogleda, da mu se nasmeje, od radosti da se zaplače kad ga zagrli, kad bi se odmah, ama odmah, isprečio on, pokojnik (Stanković 1980, 260). In the experienced speech, Anica just allows herself the thought of happiness, for guilty conscience she introduces the character of the deceased, so this counter-narrative expresses Anica's philosophy of a young widow in a patriarchal society and also motivates her action of rejecting Ita's proposal. Just as Cveta starts dreaming about happiness and love, and obsessively prays and worships God, so Anica immediately turns to asking the deceased to forgive her for daring to think about another, better life. Remarrying the unloved one, Nedeljko instead of Ita, was Anica's "redemption to the deceased, a kind of catharsis, for her the only possible one, to get rid of the heavy obsession with "the sin" that brought her to the brink of insanity" (Najdanović 2010, 346).

\subsection{Comparison}

As a subtype of virtual narrative, comparison is the process of comparing a feature or an action of a protagonist, but also other entities in the actual world of the story, to someone more familiar and closer to the protagonist or storyteller. During the hyperbolized comparison, there is a greater distance between the virtual and the actual world, which is the case in the short story Naš Božić, in which the information is presented by the child as a storyteller and focalizer. As such narration is extremely subjective, the descriptions are often colored by the infantilism of the child. The enthusiasm of the child-storyteller with the appearance of the church on Christmas makes him see lighted candles as bright stars and still 
personifies them: Sproću se sjaji ikonostas, po njemu žmirkaju zapaljena kandila, a više svega, kao zvezde trepću i prodiru ozgo upaljene sveće oko Raspeća (Stanković 1980, 176).

The characteristics of the protagonists of the short story Stanoja in the actual world of the story are doubled in the virtual world as comparisons in order to be better presented and emphasized. Kata [...] beše i radenica ko krtica (Stanković 1980, 147), Stanoja [...] radi kao crv (Stanković 1980, 145), and when Kata falls ill, he will be compared to a woman in his devotion to her children (Stanković 1980, 146). The term from the virtual narrative becomes a parameter according to which a characteristic of the protagonist from the actual world of the story qualifies. The use of comparisons in Stari dani: I kao da puče nešto (Stanković 1980, 194) aims to show effectively the festive atmosphere on Saint Michael's day. By comparison, as a type of virtual narrative, not only objects and people from the current world of the story, but also its immaterialized entities can be brought closer to the reader.

\subsection{Narrative negation}

The narrative negation is a form of virtual narrative in which an alternative world is presented, which for some reason could not exist as a parallel to the actual one, but its introduction is still important for pointing to a phenomenon in the actual world of the story. In Stanković's short story $U$ vinogradima, narrative negation is present in order to show the crowds made by horses and people during the harvest: Pa kad sve to počne da se tiska, gura, pretiče jedno drugo, onda ni kokoš ne bi mogla da prođe s jedne na drugu stranu, a kamoli čovek (Stanković 1980, 152). This narrative negation introduces a hypothetical narrative situation which, in its negative nature, aims to emphasize liveliness during the vineyard harvest, but also to describe the narrow streets of Vranje that led to the vineyards.

This form of virtual narrative is in the service of the description of Pasa, the protagonist of Stanković's short story of the idyllic tone Đurđev-dan. Pasa is idealized for her girlish chastity and shyness, which are emphasized by her physical features while the character-storyteller runs after her: "Iz zažarenih obraza tek što krv nije kanula", he will say, emphasizing her cheeks blushing with shame. Narrative negation is related to the future tense near after the moment of speech and is expressed by a relatively used verb form in the perfect while in the given example from the short story $U$ vinogradima narrative negation is expressed by a modal form of the verb negation as a hypothesis of what could not be accomplished in an alternative world.

\section{CONCLUSION}

The collection of modern short stories by Borisav Stanković Stari dani occupies an important place in the history of Serbian literature. On the borderline between realism and modernity, Stanković brings new narrative procedures and a different image of an individual in society. The protagonist acquires his second identity: in addition to the primary one, there is also the other one, which is attributed to him by the social environment. When the patriarchal environment prevents the accomplishing of a protagonist's intention or a goal, he then directs it towards another protagonist as an alternative. This structural procedure of replacing one protagonist with another has two functions: a) psychologization as a static function (Stanoja, Naš Božić, Nuška, Oni) and b) a dynamic function - in a development of a plot ( U noći, Pokojnikova žena). In 
addition to the alternatives in terms of the literary protagonist, the important narrative procedure is doubling of narrative worlds, when we talk about four types of virtual narrative: simulated narrative, counter-narrative, comparison and narrative negation. They can be motivated by the psychological states of the characters or their position in the patriarchal society from the end of the 19th century. Thus, the realistic tradition is enriched with modern artistic procedures, which makes Borisav Stanković's prose a turning point in the transition from realism to modernism.

\section{REFERENCES}

Bahtin, M. 1989. O romanu. [About the novel]. Beograd: Nolit.

Deretić, J. 2007. Istorija srpske književnosti. [History of Serbian literature].Beograd: Sezam Book.

Ivanić, D. 1996. Srpski realizam. [Serbian realism]. Novi Sad: Matica srpska.

Lešić, J. 1981. Nušićev smijeh. [Nušić's laugh]. Beograd: Nolit.

Maksimović, G. 2014. Kazivanje grada i drugi ogledi. [Telling the city and the other views]. Niš: Filozofski fakultet u Nišu.

Milosavljević Milić, S. 2013. Otpori i prekoračenja: poetika proze Bore Stankovića. [Resistances and overshoots: poetics of Bora Stanković's prose]. Niš: Filozofski fakultet.

Milosavljević Milić, S. 2016. Virtuelni narativ: ogledi iz kognitivne naratologije. [Virtual narrative: views about cognitive narratology]. Niš - Sremski Karlovci - Novi Sad: Filozofski fakultet u Nišu - Izdavačka knjižarnica Zorana Stojanovića.

Najdanović, M. 2010. Orijentalni kolorit u širem spektru lokalne boje u stvaralaštvu Borisava Stankovića, Svetozara Ćorovića i Alekse Šantića. U: Denić, S. (ur.), Borisav Stanković u Vranjskom glasniku. [Oriental coloring in extensive spectrum of local colour in Borisav Stanković's, Svetozar Ćorović's and Aleksa Šantić's creation. In: Denić, S. (ed.), Borisav Stanković in Vranje's herald]. Vranje: Književna zajednica "Borisav Stanković", 330-376.

Petković, N. 2009. Sofkin silazak: "Nečista krv" Borisava Stankovića. [Sofka's come-down]. Leskovac Beograd: Zadužbina Nikolaj Timčenko - Altera.

Richardson, B. 2014. Fictional Minds, Natural and Unnatural.In: Narrative Matters 2014: Narrative Knowing/ R'ecit et Savoir, Jun 2014, Paris, France.

Stanković, B. 1980. Stari dani/ Božji ljudi. Sabrana dela Borisava Stankovića, knj. 1. [The Old Days/ God's people. Collected works of Borisav Stanković, first volume].Beograd: Prosveta.

Vukićević, D. 2011. Anarhija teksta: ogledi o srpskoj književnosti 19. veka. [Anarchy of the text: views about Serbian literature]. Beograd: Službeni glasnik.

Vučković, R. 2014. Moderna srpska proza: kraj XIX i početak XX veka. [Modern Serbian prose: the end of $19^{\text {th }}$ and the beginning of $20^{\text {th }}$ century]. Beograd: Službeni glasnik.

Ženet, Ž. 1995. Perspektiva i fokalizacije.Reč: časopis za književnost $i$ kulturu. [Perspective and focalizations. Word: journal of literature and culture]. (8/1995). 83-86.

\section{UDVAJANJA U ZBIRCI PRIPOVEDAKA STARI DANI BORISAVA STANKOVIĆA}

U radu će biti sagledano udvajanje identiteta likova u zbirci pripovedaka Borisava Stankovića Stari dani (1902), kao i svesno ili nesvesno biranje nekog drugog junaka kao alternative za izvršenje određene junakove aktivnosti. Zatim će biti analizirano udvajanje aktuelnog narativnog sveta kroz kontrapripovest, simulirani narativ, poređenje i narativnu negaciju. Pokušaćemo i da odgovorimo na pitanja na koji način patrijarhalni kontekst uslovljava ovaj alteritet svetova $i$ junaka $i$ kakve to uzročno-posledične veze ima sa psihologizacijom Stankovićevih junaka $i$ razvojem radnje u devet pripovedaka pomenute zbirke.

Ključne reči: Borisav Stanković, udvajanje identiteta, zamena junaka, virtuelni narativ, Stari dani 